\title{
股関節手術後の深部静脈血栓症，肺血栓塞栓症の発生について
}

$\begin{array}{llllll}\text { 依 } ⿴ 囗 十 ~ & \text { 周* 榎 本 } & \text { 寛* }^{*} \text { 岡 野 邦 彦* } \\ \text { 尾 崎 } & \text { 誠* 松 林 昌 平 }{ }^{*} \text { 進 藤 裕 幸* }\end{array}$

\section{Occurrence of Deep Venous Thrombosis and Pulmonary Thromboembolism after Hip Joint Operation}

Itaru Yoda*, Hiroshi Enomoto*, Kunihiko Okano*, Makoto Osaki*, Shouhei Matsubayashi*, and Hiroyuki Shindo*

我々は H14 年まで股関節手術患者に系統的な血栓予防を施行せず，術後致死的な DVT, PE 経験した。 以後，股関節手術患者に対し全例血栓のスクリーニングと予防を施行することにしている。今回 H15 年 7 月から $\mathrm{H} 18$ 年 6 月までの当院で手術した股関節手術例 149 例について線溶系マーカーと深部静脈血栓症 (DVT), 肺血栓塞栓症（PE）の関連について調査したので報告する。当院での術後血栓症スクリーニング と対処方法は, FDP, D-dimer を術前後に測定し, 術後 D-dimer 值が $30 \mu \mathrm{g} / \mathrm{ml}$ 以上例または臨床症状出 現例に対して造影 CT による血栓調査を施行した。結果は造影 CT 施行は 9 例であり D-dimer 值 $30 \mu \mathrm{g} / \mathrm{ml}$ 以上が 8 例, 下肢腫脹のみが 1 例であった. 血栓発症例は 7 例であり全例 D-dimer が $30 \mu \mathrm{g} / \mathrm{ml}$ 以上であっ た。うちわけは DVT 単独が 2 例, DVT と PEが 5 例であった。我々は発症が上昇する $20 \mu \mathrm{g} / \mathrm{ml}$ 以上につ いて今後，スクリーニングを続けていこうと考えている.

The purpose of this study is to investigate the relevance if plasmin marker (FDP : Fibrin Degradation Product, D-dimer) and the occurrence of deep venous thrombosis (DVT) / pulmonary thromboembolism (PE).

We report 149 cases undergoing hip joint operation from July 2003 to June 2006. We measured FDP and D-dimer before and after operation, and performed contrasting CT when the D-dimer value was more than $30 \mu \mathrm{g} / \mathrm{ml}$.

Nine cases were checked by contrasting CT. Thrombosis was found in seven cases, in which only two were DVT, while the others were DVT and PE. We perform this screening when D-dimer values are above $20 \mu \mathrm{g} / \mathrm{ml}$.

Key words : DVT (深部静脈血栓症), PE (肺血栓塞栓症), D-dimer (D ダイマー), FDP (フィブリン分 解産物), hip joint (股関節)

\section{は じめ に}

深部静脈血栓症（以下 DVT），肺血栓塞栓症（以 下 PE）は2004 年に予防ガイドラインが公表され， 予防, 診断, 治療は整形外科領域において合併症の重 要なものの一つに挙げられるようになった2235). 今 回我々は当科における股関節手術例の線溶系マーカー (FDP, D-dimer) とDVT, PE 発症との関連につい て調査したので報告する.

\section{対象および方法}

$\mathrm{H} 15$ 年 7 月から $\mathrm{H} 18$ 年 6 月までの当院で手術した 股関節手術例 149 例（男性 28 例 女性 121 例）の手 術法は人工股関節置換術 106 例, 骨盤骨切り術 43 例であった。原疾患は变形性股関節症 137 例, 大腿 骨頭壊死症 12 例であり手術時年齡は $22 \sim 82$ 歳, 平 均 58.4 歳であった。

当科では PE, DVT の危険因子は 2003 ガイドライ ン合同研究班報告 ${ }^{3)}$ (表 1 ）に基づき, 静脈血栓症の 既往と血栓性素因のみ高度危険因子とし，その他は全

\footnotetext{
* 長崎大学整形外科 Department of Orthopaedic Surgery, Nagasaki University, Nagasaki, Japan
} 
て中等度危険因子として，項目数でリスク度を決めて いる.

当科での予防の現状は，全例に間歇的空気圧迫法を 施行し，高リスク群には加えてアスピリン $100 \mathrm{mg} を$ 2 週間施行し，最高リスク群にはヘパリン 5000〜 1 万 単位を 3 日〜 4 日間とワルファリン $2 \sim 5 \mathrm{mg}$ を 2 週 間施行している (表 2 )。今回の調査では高リスク群 は 144 例, 最高リスク群は 5 例であった。

\begin{tabular}{|c|c|}
\hline 強度 & 危険因子 \\
\hline 弱い & 肥満, エストロゲン治療, 下肢静脈瘤 \\
\hline 中等度 & $\begin{array}{l}\text { 高齢, 長期臥床, 槐血性心不全, 呼吸 } \\
\text { 不全, 悪性疾患, 中心静脈カテーテル } \\
\text { 留置, 癌化学療法, 重症感染症 }\end{array}$ \\
\hline 強い & $\begin{array}{l}\text { 静脈血栓症の既往, 血栓性素因, 下肢 } \\
\text { 麻痺, 下肢ギプス包帯固定 }\end{array}$ \\
\hline
\end{tabular}

2002-2003 ガイドライン合同研究班報告

表 2 当科での PE・DVT 予防の現状

\begin{tabular}{c|c}
\hline \hline \multicolumn{2}{c}{ 全例に間歇的空気圧迫法 } \\
\hline 中等度リスク群 & $\begin{array}{l}\text { 高度リスク群 } \\
\text { (危険因子 3 項目まで) } \\
\text { (危険因子 } 4 \text { 項目以上 or 静脈 } \\
\text { 血栓症の既往・血栓性素因) }\end{array}$ \\
\hline アスピリン 100m g/日× & ヘパリン $5000 \sim 1$ 万単位 \\
2 週間 & $\times 3 \sim 4$ 日 \\
& +ワルファリン $2 \sim 5 \mathrm{mg}$ \\
& $\times 2$ 週間 \\
\hline 144 例 & 5 例 \\
\hline
\end{tabular}

当科での術後血栓症スクリーニングと対処方法は FDP と D-dimer 老術前後に測定し, 術後 D-dimer 值が $30 \mu \mathrm{g} / \mathrm{ml}$ 以上例または臨床症状出現例に対して 造影 CT による血栓調查を施行した（図 1 ).

結果

造影 CT 施行は 9 例であり, D-dimer 值 $30 \mu \mathrm{g} / \mathrm{ml}$ 以上が 8 例, 下肢腫脹のみが 1 例であった。血栓発症 例は 7 例であり全例 D-dimer が $30 \mu \mathrm{g} / \mathrm{ml}$ 以上であっ た。うちわけは DVT 単独が 2 例, DVT と PEが 5 例であった。

D-dimer, FDP は術前, 術後 1 週，術後 2 週にお いてほぼ同様の増加傾向を示した（図 2)

術前值の比較では D-dimer は半数以上が正常值を 越える 1 以上であった（図 3 )。正常值の 1 未満では 発症がなく, 発症例は全例 1 以上であった。一方, FDP は正常值の 5 未満であっても発症が見られた。

D-dimer 值の血栓陽性例 と陰性例の比較では術前 值では 2 倍, 術後 1 週で 3 倍, 術後 2 週で 4 倍近く陽 性例が高值を示した（図 4 ).

術後 1 週の D-dimer 值は $10 \mu \mathrm{g} / \mathrm{ml}$ から $20 \mu \mathrm{g} / \mathrm{ml}$ で 1 例の血栓陽性例, $20 \mu \mathrm{g} / \mathrm{ml}$ から $30 \mu \mathrm{g} / \mathrm{ml}$ では 3 例の陽性例, $30 \mu \mathrm{g} / \mathrm{ml}$ 以上では 3 例全例の陽性が 確認された（図 5 ).

術後 2 週では $20 \mu \mathrm{g} / \mathrm{ml}$ から $30 \mu \mathrm{g} / \mathrm{ml}$ で 2 例, 30 $\mu \mathrm{g} / \mathrm{ml}$ 以上で 5 例の陽性例が見られた（図 6 ).

DVT/PE の発症は 9 例中 7 例であり全例 THA を 施行した女性であった。2 例が DVT のみで 5 例は $\mathrm{PE}$ も発症していたが胸部症状を呈したのは 1 例のみ

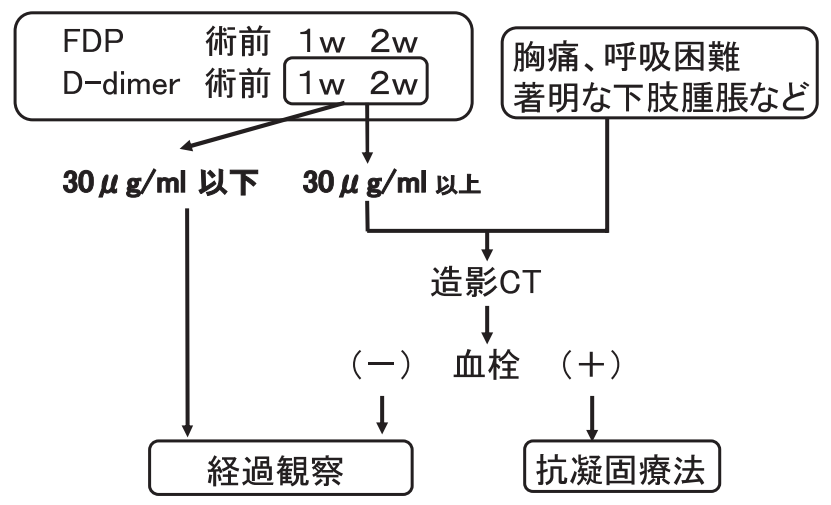

図 1 術後血栓症スクリーニングと対処方法 


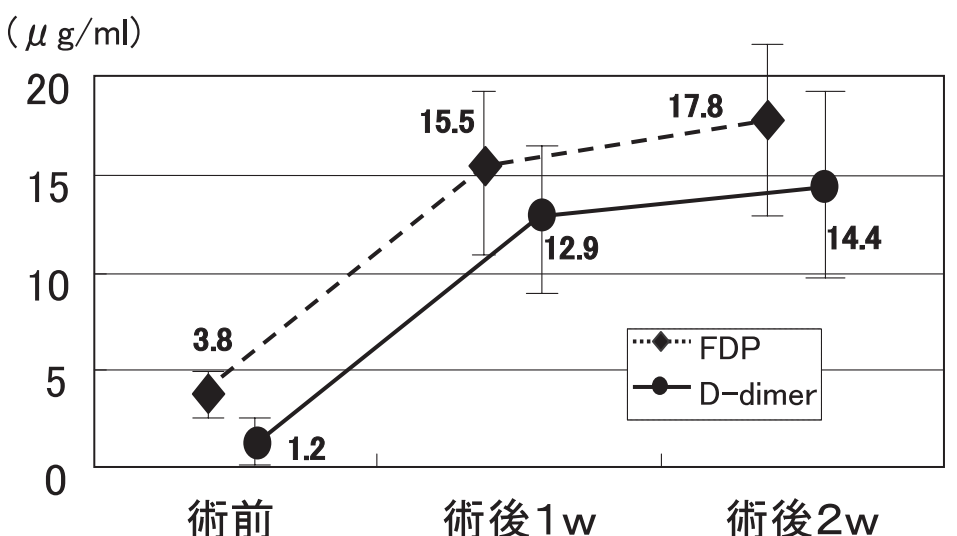

図 2 D-dimer 值と FDP 值の推移
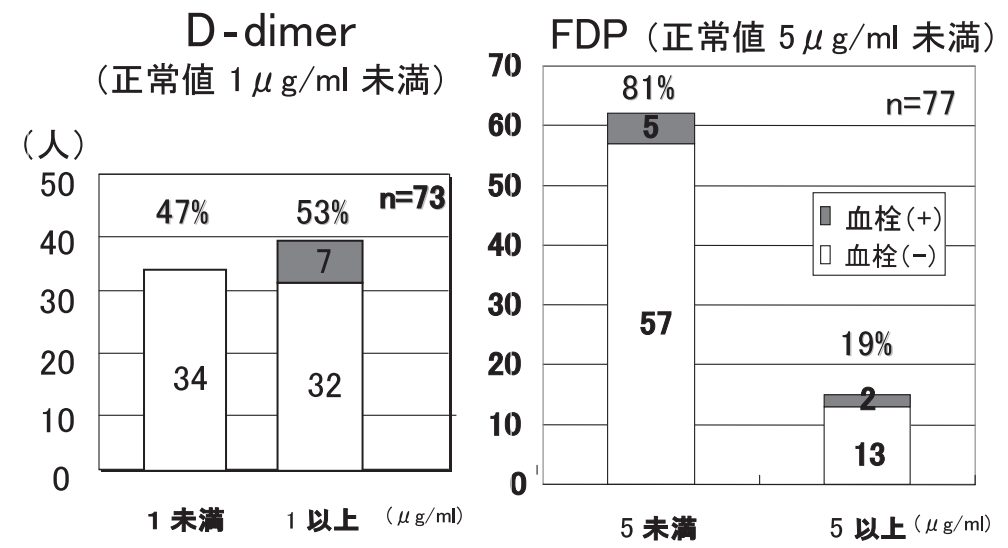

図 3 D-dimer, FDP 術前値の比較

であった。 ヘパリン投与群での発症も認められた。術 前の D-dimer は全例 1 以上であり, 特に PE 発症例 では 1.9 以上の高值を示した。治療は胸部症状を呈し た例にはt-PA（組織プラスミノーゲンアクチベーター） が投与され，それ以外にはヘパリンとワルファリンを 投与されている (表 3 ).

\section{考察}

今回我々は DVT/PE 予防としてアスピリンとへパ リン/ワルファリンを投与してきたがそれにあ関わら ずDVT/PEの発症を認めた. アスピリン投与に関し ては否定的な意見ああり今後見直す必要があると考え ている。ヘパリン/ワルファリン投与については投与
量について問題があるかもしれない。 PT－INR を 1.5〜2.5 の範囲で調節するなど調整が必要であると考 えている.

Jorgensen ら ${ }^{4)}$ は術後の DVT 発症については FDP，D-dimer ともに高值を示すと述べている．特 にD-dimer は図 7 に示すようにフィブリン（血栓） にプラスミンが作用する二次線溶時の生成産物であり, 尾崎ら ${ }^{6)}$ はフィブリノゲン由来の分解産物 (一次線溶) も反映する FDP と比べて二次線溶に特性が高いと述 べている. 術後 1 週の D-dimer 值に関する報告では 立花ら ${ }^{7)}$ は $\mathrm{THA}$ 術後 1 週間值が $10 \mu \mathrm{g} / \mathrm{ml}$ 以上で DVT 発症の可能性が高いと報告している。また Akman ら ${ }^{1)}$ はDVT を除外するためには信頼性が高 
( $\mu \mathrm{g} / \mathrm{ml})$

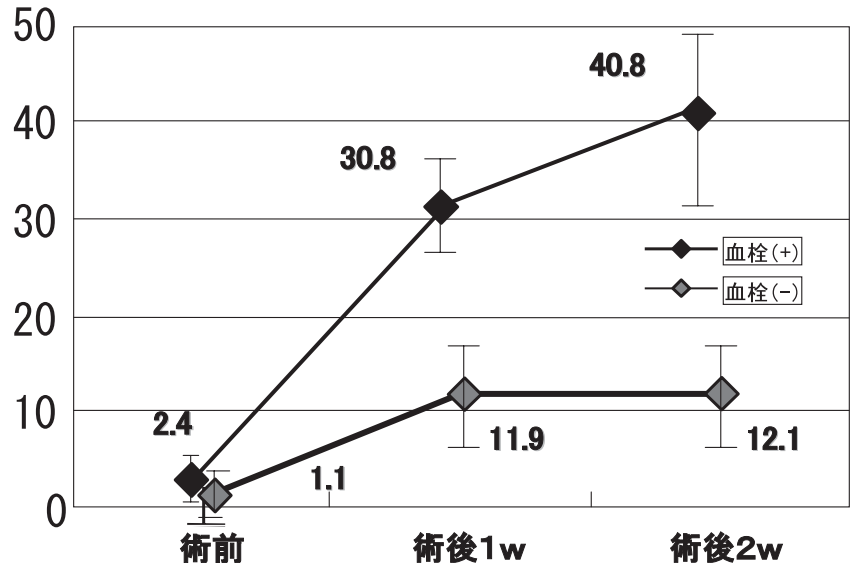

図 4 D-dimer 值

- 血栓陽性例之陰性例 -

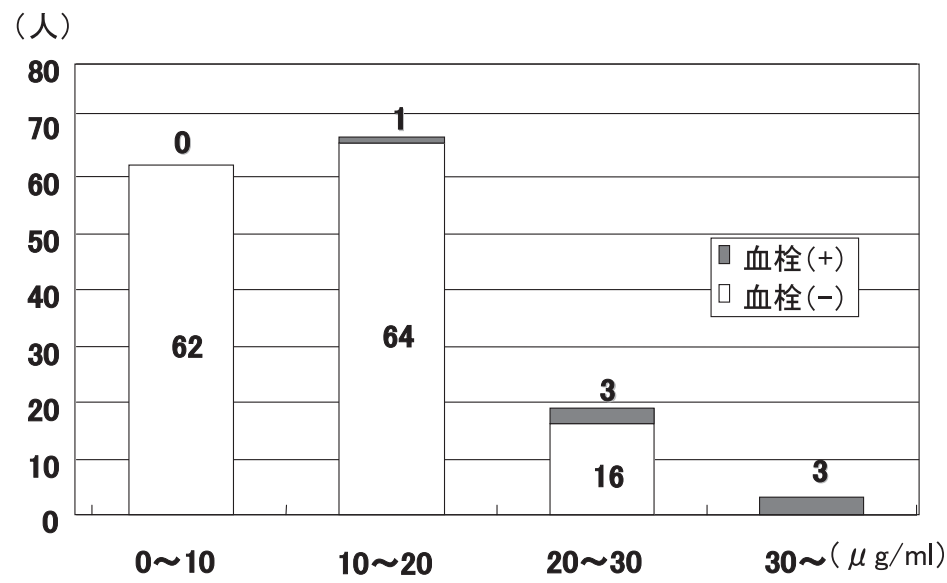

図 $51 \mathrm{w}$ 後の D-dimer 值

い方法であると報告している。1 週後の D-dimer 值 を見てみると確かに 10 以下では発症は認めず，それ 以上から発症例は認められた。しかしカットオフ值の $10 \mu \mathrm{g} / \mathrm{ml}$ 以上は全体の $59 \%$ を占め，この例全てを 造影 CT 施行することは現実的には困難であると考元 る. 我々は発症が上昇する $20 \mu \mathrm{g} / \mathrm{ml}$ 以上について今 後，スクリーニングを続けていこうと考えている.
ま と め

- $\mathrm{H} 15$ 年 7 月から $\mathrm{H} 18$ 年 6 月までの股関節手術例 149 例について線溶系マーカーと深部静脈血栓症 (DVT), 肺血栓塞栓症（PE）の関連について調 査した。

・ 術後 D-dimer 值が $30 \mu \mathrm{g} / \mathrm{ml}$ 以上例では高率に血 栓の発生を認めた。 


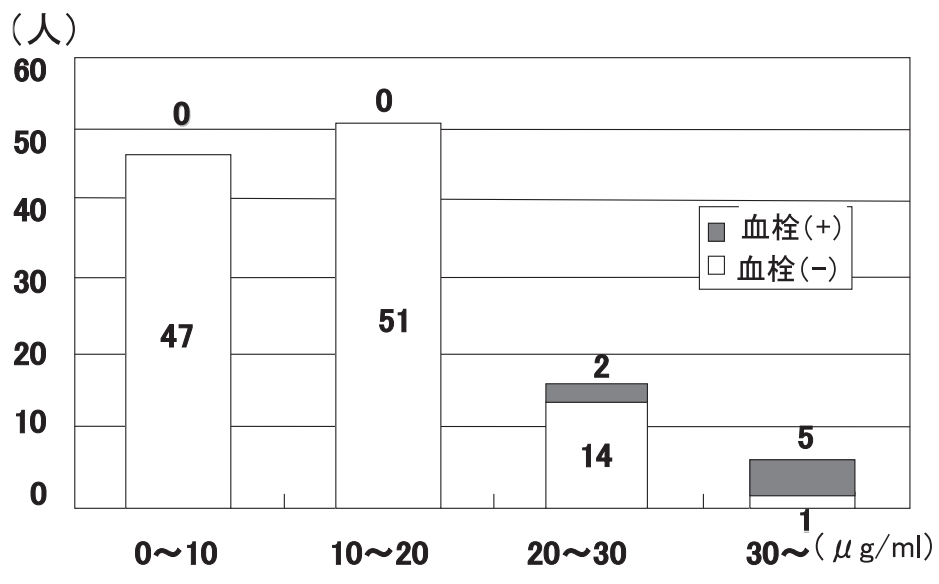

図 $62 \mathrm{w}$ 後の D-dimer 值

表 3 PE・DVT 発症例

\begin{tabular}{|c|c|c|c|c|c|c|c|c|}
\hline 年齢, 性別 & 手術 & 診断 & 症状・所見 & 予防 & DD 術前 & DD 1W & DD 2W & 治療 \\
\hline $77, \mathrm{~F}$ & THA & $\mathrm{D}$ & 下肢腫脹 & Asp & 1.3 & 36.9 & 28.6 & Hep+War \\
\hline $56, \mathrm{~F}$ & THA & $\mathrm{D}$ & 下肢腫脹 & Asp & 1.8 & 58.1 & 23.5 & Hep+War \\
\hline $54, \mathrm{~F}$ & THA & $\mathrm{D}+\mathrm{P}$ & 胸痛, $\mathrm{O}_{2}$ 低下 & Asp & 2.3 & 24.6 & 43.1 & t-PA \\
\hline $82, \mathrm{~F}$ & THA & $\mathrm{D}+\mathrm{P}$ & 下肢腫脹 & Hep 5000 & 3.2 & 17.1 & 74.1 & Hep+War \\
\hline $70, \mathrm{~F}$ & THA & $\mathrm{D}+\mathrm{P}$ & 下肢腫脹 & Asp & 1.9 & 27.6 & 35.9 & Hep+War \\
\hline $53, \mathrm{~F}$ & THA & $\mathrm{D}+\mathrm{P}$ & 下肢腫脹 & Asp & 3.3 & 23.6 & 49.6 & Hep+War \\
\hline $78, \mathrm{~F}$ & THA & $\mathrm{D}+\mathrm{P}$ & 下肢腫脹 & Asp & 3.5 & 35.4 & 31.0 & Hep+War \\
\hline
\end{tabular}

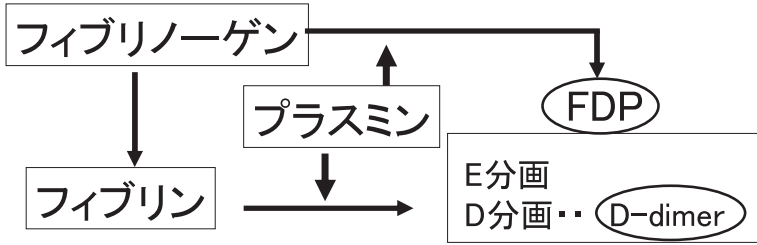

図 7 線溶系

\section{参 考 文 献}

1) Akman, M. N., et al. : Value of the D-dimer test in diagnosing deep vein thrombosis in rehabilitation in patients. Arch. Phys. Med. Rehabil., 85(7) : 1091-1094, 2004.
2）富士武史：整形外科術後肺血栓塞栓症・深部静脈血栓 症マニュアルーガイドラインに基づく予防・診断・治療 の実際, pp.45-49. 東京, 南江堂, 2005 .

3）肺血栓塞栓症/深部静脈血栓症（静脈血栓塞栓症）予 防ガイドライン作成委員会 : 肺血栓塞栓症/深部静脈血栓 症 (静脈血栓塞栓症) 予防ガイドライン・ダイジェスト版. Medical Front International Limited : 15-16, 2004. 


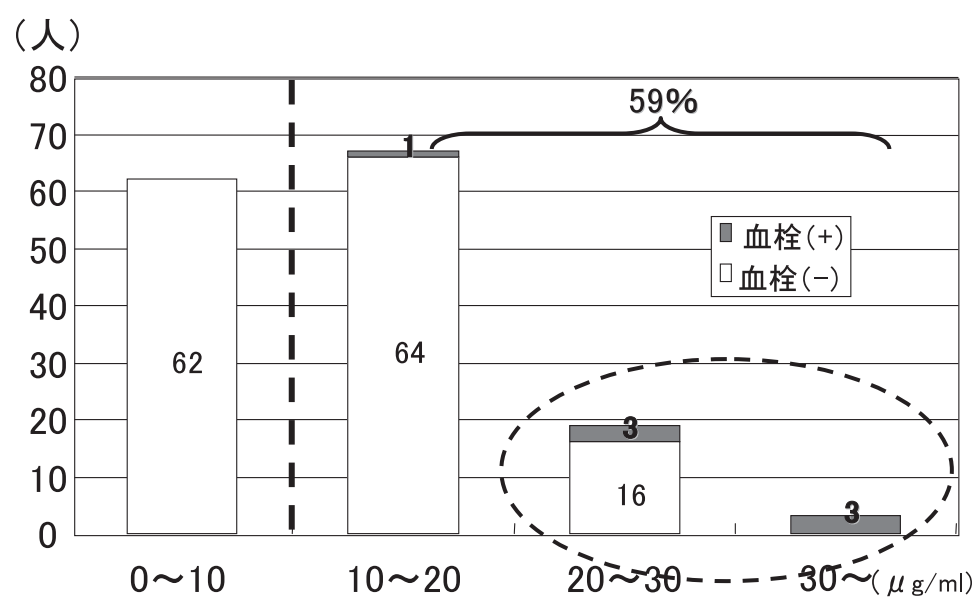

図 8 D-dimer 值（術後 $1 \mathrm{w}$ )

4) Jorgensen, L. N., et al. : Thrombin-antithrombin III-complex \& fibrin degradation products in plasma : surgery and postoperative deep venous thrombosis. Thromb. Res., 59 (1) : 69-76, 1990.

5) 中野 赳: 第 7 回 ACCP ガイドライン一静脈血栓塞栓 症の予防扮よび妊娠中の抗血栓薬の使用。Medical
Front International Limited : 3-5, 2006.

6）尾崎由基男：血栓症を血液で診断する一血栓形成のマー カー.メディチーナ，41:936-938, 2004.

7）立花新太郎：下肢手術後の肺塞栓症の診断. 整・災外, 44 : 1169-1178, 2001. 